\title{
Vállalkozói vezetöi kompetenciák a Hangavári Pincészet esete tükrében
}

\author{
Kassai Ákos \\ Budapesti Corvinus Egyetem
}

\begin{abstract}
A TANULMÁNY CÉLJA
Ez a publikáció egy több lépésből álló kutatássorozat első eredményeit mutatja be. Az első lépés azt tűzte ki célul, hogy megvizsgálja, beazonosítható-e a vezetői kompetenciák olyan csoportja, amelyek megléte segíti a vállalkozások alapítóinak, vezetőinek munkáját. A kutatás fỏ kérdése az, hogy létrehozható-e olyan vezetői kompetencia modell, aminek az alkalmazása segít beazonosítani a vállalkozók számára szükséges vezetöi feladatok sikeres ellátásában. Amennyiben ilyen kompetenciamodell kialakítható, annak számos gyakorlati haszna lehet. Segítséget nyújt majd üzleti iskolák vállalkozói kompetenciafejlesztő programjainak kialakításához, hatékonyabbá teheti a kockázatitőke-befektetők kiválasztási és portfolió-kezelési gyakorlatát. Fontos segítséget nyújthat továbbá a vállalkozói inkubátor és akcelerátor programok tervezői és megvalósítói számára és növelheti a vállalkozói szektorban dolgozó tanácsadók munkájának hatékonyságát is.
\end{abstract}

\section{MÓDSZERTAN}

A feltáró kutatásban, irodalomkutatást követően egy magyar tulajdonú, generáció-váltáson részben átesett, borászati vállalkozás esettanulmányán keresztül azonosítottam a speciálisan jellemzö és a sikerhez szükséges vezetői kompetenciákat. Az egyes jellemző kompetenciák azonosítását tartalomelemzéssel, végeztem el, amely eredményeit kvalitatív és egyszerü kvantitatív elemzésnek is alávetettem.

\section{LEGFONTOSABB EREDMÉNYEK}

Az esettanulmány alapján öt kompetenciacsoport azonosítható be, amelyek leírják egy vállalkozás indításához és sikeres vezetéséhez szükséges kompetenciakészlet elemeit: személyes késztetés, tervező, szociális, végrehajtó és szervezeti. Ritka, hogy egy személy rendelkezzen egy ilyen diverzifikált kompetenciakészlettel. Családi vagy társas vállalkozások tagjai együttesen jobb eséllyel rendelkeznek a szükséges sokrétủ vezetöi kompetenciákkal.

\section{GYAKORLATI JAVASLATOK}

A vállalkozók hasonló szerepet játszanak egy vállalat fejlödése életében, mint az össejtek az élő szervezet fejlődésében. Míg az őssejt tartalmazza azt a képességet, hogy a későbbi élö szervezet minden egyes differenciált sejtje, szövete és szerve fejlődéséhez biztosítsa az információt és ez által a képességet, úgy a sikeres vállalkozók rendelkeznek azokkal a kompetenciákkal, amelyek elemei egy differenciált üzleti szervezet kialakulásának.

A beazonosított 5 kompetenciacsoportból az egyéni-kompetenciák a vállalkozás indításához szükséges személyes motivációt tartalmazzák és minden vállalkozó számára szükséges kompetencia. A tervezés, megvalósítás és szociális kompetenciacsoportokat a vállalkozók eltérő mértékben használhatják egyéni vezetési stílusuk alapján. Az 5. kompetenciacsoport elemei, a szervezeti -kompetenciák, érettebb vállalkozásoknál játszanak fontos szerepet és segítik a vállalkozót a kisvállalkozás kereteiből kilépni és nagyobb, formalizált szervezetet és komplexebb üzleti folyamatokat igénylő vállalatot építeni.

Kulcsszavak: vállalkozás, vezetés, kompetenciák, családi vállalkozás

DOI: 10.15170/MM.2020.54.01.07 


\section{VÁLLALKOZÓI VEZETŐI KOMPETENCIÁK}

\section{ENTREPRENEURIAL LEADER- SHIP COMPETENCIES}

Az 1980-as évektől kezdődően a vezetői kompetenciák egyre fontosabb szerepet játszanak a vezetéstudomány és a szervezeti magatartás kutatások területén. A XX. századi kutatások jelentős része a kompetenciák definiálásáról és felhasználási területük kijelöléséről szólt. A kompetenciák meghatározásában mérföldkövet jelentettek Boyatzis (1982), továbbá Spencer és Spencer (1992) eredményei, amelyek szerint „A kompetenciák egy személy alapvető meghatározó jellemzői, melyek okozati kapcsolatban állnak a kritériumszintnek megfelelő hatékony és-vagy kiváló teljesítménnyel" (Boyatzis 1982, 21). Spencer és Spencer (1992) ezt a definíciót azzal egészíti ki, hogy a kompetenciák általánosíthatók eseteken és szituációkon keresztül és ésszerü időtávon belül állandók maradnak. Fontos jellemzője a kompetenciáknak, hogy megbízhatóan mérhetők, ezáltal alkalmas célpontjai lehetnek társadalomtudományi kutatásoknak.

A kompetenciákat a menedzsment-szakirodalomban gyűjtőfogalomként használják. A kompetencia valójában olyan készlettár, amelybe kerülhetnek személyiségjellemzők, motivációk, készségek, képességek, speciális ismeretek, módszertani ismeretek, tudás, stb., amelyek a munkahelyi szituációkhoz kapcsolhatók (Sandberg 2000, Tóthné-Hlédik 2018).

Egyik legfrissebb, és ebben a kutatásban legjobban alkalmazható, meghatározás Tittel és Terzidis (2020) meta-analysizisen alapú elemzése. A vállalkozói kompetenciákat vizsgáló tanulmányukban a szerzők a kompetenciákat úgy értelmezik, hogy az egyén azon hajlandósága, hogy megfelelő lépéseket hozzon a változó helyzetekben a problémák felelősségteljes megoldására. Ez a képesség tudáson, készségeken és hozzáálláson alapul.

A vezetői kompetenciák kutatásának előfutára volt 1940-es és 1950-es években a vezetői tulajdonságokon alapuló leadership megközelítések. „A 40-50-es évek leadership kutatásai azt vizsgálták, milyen tulajdonságok jellemzik a sikeres vezetőket, következésképpen milyen tulajdonságokkal kell rendelkezniük azoknak, aki jó vezetővé akarnak válni” (Bakacsi 2010, 32.). Bakacsi szerint ezen időszak eredményei meglehetősen ellentmondásosak voltak.
A XXI. századi kutatások már egységesebbek és specifikusabbak lettek. Többek között kiterjedtek arra is, hogy egyes sajátos vezetői feladatok sikeres teljesítéséhez milyen speciális kompetenciacsoport alkalmazása szükséges. Ezek a kutatások részben akadémiai, részben vállalati, alkalmazott kutatások voltak, leginkább kvalitatív módszereket használva. A legnagyobb multinacionális vállalatok jellemzően tanácsadócégek bevonásával próbálnak meg kialakítani kompetenciamodelleket, amelyek alapján választják ki, értékelik, képzik jelenlegi és jövőbeni vezetőiket. A vezetési tanácsadók ezzel egy időben kezdik el új termékként kínálni a kompetencia alapú kiválasztási, értékelő fejlesztési és javadalmazási rendszereiket.

A vállalkozók fejlesztése kapcsán gyakorta említik a vezetőfejlesztést, mint tevékenységet. Számos forrás mutat rá arra, hogy a vállalkozók fejlesztése nem más, mint vezetőfejlesztés (Zsigmond 2018). Definiciók is születtek már vállalkozói kompetenciák azonosításához. Mihalkovné szerint az egyén kiemelkedő teljesítményét elősegítő egyfajta tudás-, viselkedés-, képesség-, készség- vagy magatartásegyüttest a vállalkozások vezetése, a vállalkozások menedzselése és növekedésre segítése, mint adott feladat területén értelmezzük, úgy eljutunk a vállalkozói kompetencia fogalmához (Mihalkovné 2014).

\section{KI A VÁLLLAKOZÓ?}

\section{WHO IS AN ENTEPRENEUR?}

A korai fázisú vállalkozásokat és így a vállalkozókat is leggyakrabban a Churchill és Lewis (1983) által beazonosított 5 fejlödési szakasz első két elemében lévő vállalkozás vezetőivel azonosítják: „koncepcióalkotás” és „túlélés”. Ezen kutatás definíciója bővebben határozza meg a vállalkozásokat és vezetőiket. A kutatásom központjában olyan gyakorló vállalatvezetők vannak, akik vagy alapítói a társaságnak, vagy az alapítás után csatlakoztak, de jelentős tulajdonrészük van az adott vállalatban.

Nehéz definiálni, hogy mit jelent pontosan a jelentős részarány kifejezés. Mivel a kutatás központjában a személy és nem a vállalat áll, ezért a valósághoz, akkor járunk a legközelebb, ha a vállalkozó egyén szempontjából és nem a társaság irányából közelítjük ezt a problémát. A kutatás során azt tekintem vállalkozónak, aki közép-, és hosszú távú jövedelmének túlnyomó részét a társaságban lévő tulajdonviszonya alapján, tőkeágon, és nem munkabérként, alkalmazottként kapja vagy reméli. 
A kutatásnak így alanyai lehetnek nem pusztán korai fázisban lévő vállalkozások vezetői, hanem - szintén Churchill és Lewis (1983) alapján - az érettebb fázisokban lévő vállalatok vezetői, amenynyiben jelentős tulajdoni tőkejövedelem reményében dolgoznak. Habár a fenti definíció bővebb, mint ha csak az életszakasz alapján definiálnánk a vállalkozókat, de emellett a figyelmem nagyobb része mégis a két korai fázisra irányul. Történik ez azért, mivel a későbbi fázisokban, leginkább a harmadik ,siker fázisban, jellemzően elválik egymástól a management és a tulajdonosi szerepkör (Churchill \& Lewis 1983) és ebben az esetben már kisebb mértékben, de nem példa nélkül, beszélhetünk vállalkozók által vezetett vállalatokról. A két fent említett korai fázisban szinte kizárólag tulajdonosok, azaz vállalkozók vezetik a sikeres társaságokat.

Történtek korábbi kutatások vállalatvezetők számára szükséges kompetenciák azonosítására, a vállalkozás életszakasza alapján. Ilyen példa Eggers, Leahy és Churchill (2009) közleménye, amelyben a vállalkozások fent is említett öt fejlödési szakaszára azonosít szükséges vezetői kompetenciákat. Ezzel azt feltételezik, hogy nincsenek egységes vállalkozói vezetői kompetenciák, hanem azok a vállalkozás életszakaszától függően változnak. A mai napig nem alakult ki egy szakmai konszenzus a fenti meghatározás alapján értelmezett vállalkozókra egyedileg jellemző kompetencia modelljére. Robles és Zárraga-Rodrígues (2015) tett kísérletet Dephi-módszer alkalmazásával vállalkozói kompetenciák azonosítására. Az eredmények használhatósága a vezetői kompetenciák tekintetében legalább is kérdéses, mivel a vezetést egy külön kompetenciaként értékelni egyenrangú kategóriaként például az önbizalommal vagy a tárgyalásra vonatkozó kompetenciával.

Kyndt és Baert (2015) munkája alapján a kockázat vállalása és annak kezelésének módját kell vizsgálni, hogy megértsük a legfontosabb vállalkozói kompetenciákat. Tervezéssel és iparági ismeretekkel, mint kulcs-vállalkozói kompetenciákkal kezelhető a kockázat. Kutatásukban a kitartást és a speciális piaci ismeretek találták olyan vállalkozói kompetenciáknak, amelyek a legalább közép-távú (3-5 éves) vállalkozói karriert támogatják. Raşcă és Deaconu (2018) a vállalkozói siker szempontjából megkülönböztet vállalkozói és management kompetenciákat. Az előbbieket a vállalkozások indításához tartják szükségesnek még az utóbbit a vállalkozások sikerre viteléhez járulnak hozzá.

Buzady és Almeda (2019) 3,4,5 és 6 szintü vállalkozói kompetenciamodelleket szintetizált. A klasszikus 3 tényezős modell a vállalkozói képességet, a kapcsolatteremtés és a cselekvés képességét említi vállalkozói kompetenciaként. A 4-tényezős modell, az előző elemeken túl, a tervezési és az eredmények elérésének kompetenciáját tartalmazza, de elhagyja a 3-szintü modell általános vállalkozói kompetenciáját. A szerzőpáros az 5-tényezős modell esetén beszél először vezetői kompetenciákról, a munkatárakkal való kommunikáció és motiváció alapján. A 6-szintü modell az iparági ismeretekkel bővíti az 5 szintű modellt. A szerzők szintén számos utalást találtak arra, hogy a szerteágazó vállalkozói kompetenciák szükségesek egy sikeres vállalkozás vezetéséhez. Ez a sokrétü kompetencia-készlet inkább vállalkozó-csapatokban, mintsem egy személy vállalkozóban található meg.

Tittel és Terzidis (2020) meta-analízise 3 fó csoportot talál a vállalkozói kompetenciák szakirodalmát vizsgálva: személyes, tudás alapú és kapcsolat alapú kompetenciák azok, amelyekre a vállalkozóknak végső soron szükségük van.

\section{ALKALMAZOTT MÓDSZERTAN}

\section{APPLIED METHODOLOGY}

A feltáró kutatásban, irodalomkutatást követően egy magyar tulajdonú, generációváltáson részben átesett, borászati vállalkozás esettanulmányán keresztül azonosítom a speciálisan jellemző és a sikerhez szükséges vezetői kompetenciákat. Külön figyelmet szentel a tanulmány az esetben szereplő vállalkozók esetleges kompetenciahiányaira, illetve azok következményeire a vállalkozás fejlődése során. Erre a célra az esettanulmány módszere kifejezetten alkalmas. „A legtöbb definíció egyetért abban, hogy az esettanulmányok számos célt teljesíthetnek: egy jelenség rendkívül alapos leírását adhatják, elméleteket tesztelhetnek vagy újabb elméleteket hozhatnak létre" (Horváth - Mitev 2015, 130-131).

Az esettanulmány feldolgozása során választ keresek a miért és a hogyan kérdéseire. Miért pont ezek a kompetenciák emelkednek ki a többi közül és hogyan befolyásolják a vállalkozók mindennapi tevékenységét a siker eléréséhez vezető úton? Az esettanulmány írása során 7 strukturálatlan interjút készítettem. Az interjúalanyok a vállalkozó Hudácskó család ma élő három tagja - Katalin, Anita és Attila, két hosszútávú alkalmazott, két nagy ügyfél, illetve egy iparági, borászati szakértő voltak. Az interjúk mellett résztvevő megfigyelést is végeztem, amely során a föszereplőket személyes közegében, napi munkavégzése során figyeltem meg és vontam le következtetéseket. Az eset- 
tanulmány készítése során dokumentumelemzést is végeztem, amelyek segítettek megérteni az esetek környezetét, időbeni fejlődését. Ilyen dokumentumfeldolgozás például az esettanulmány során bemutatott pénzügyi eredményeik vagy a borászat elismerései. Végül kisebb mértékben, de végeztem fizikai tárgyak tanulmányozását, beleértve a borkóstolást is.

A kompetenciák azonosításánál a Leadership Competencies Library 120-elemú kompetencia-adatbázisát vettem alapul. A Leadership Competency Library egyedülálló, átfogó, enciklopédia jellegű kompetencialeltár. Mára már 28 országban használják, elsősorban kiindulópontként speciális vezetői kompetenciamodellek megalkotásához. A forrás a 120 kompetencia részletes leírását, jellemzó gyakorlati előfordulását, a kompetencia meglétének lehetséges következményeit mutatja be.

A kutatás célja annak a megválaszolása, hogy a 120 elemű lista szükíthető és strukturálható-e oly módon, hogy egy a vállalkozókra jellemző specializált kompetenciahalmaz legyen azonosítható. Kiemelhetők-e kompetenciák, amelyek jellemzők a vállalkozókra. További kérdés, hogy a vállalkozók egy egységes kompetenciakészletet használnak-e vagy eltérő, jellemző vezetői kompetenciakészletekre támaszkodnak.

Az egyes jellemző kompetenciák azonosítását az esettanulmány kódolásával végeztem el, amely eredményeit kvalitatív és egyszerü kvantitatív elemzésnek is alávetettem. Az esettanulmány kódolása az eredeti esettanulmány szövege alapján történt. Az eredeti esettanulmány, terjedelemi korlátok miatt, itt nem kerül közlésre. Az esettanulmány elemzése során zárójelben jelzem a kompetencia-leltárból azonosított kompetenciákat. A kódolás során az itt jelzett kompetenciáknál több került azonosításra, amelyeket felhasználtam a cikkben közölt elemzések során is.

\section{A HUDÁCSKÓ CSALÁD ÉS A HANGAVÁRI PINCÉSZET TOKAJBAN}

\section{HUDÁCSKÓ-FAMILY AND THE HANGAVÁRY WINERY IN TOKAJ}

A Hudácskó-család Bodrogkeresztúron egy rendkívül agilis vállalkozó család, akik a szocializmus évei alatt, az akkor adott szúkös jogi keretek között, kezdték el lefektetni a vállalkozásuk alapjait. Hudácskó János és Katalin 1975-ös házasságkötésüket követően kiegészítő, kereskedelmi jelleggel, folyamatosan szőlészkedtek és családi fogyasztásra hobby-borászkodtak. A kiegészítő tevékenységből 1989-en lett vállalkozás, amikor a Tokaji Borkombinát egyszer csak nem vette át a megtermelt szőlőt és nemsokkal később Katalin elvesztette az állást is a Borkombinátban, ahol addig laboránsként dolgozott. A rendszerváltozás hozta kényszert ők, mint lehetőség élték meg. Az elsők között voltak, akik borászati vállalkozásba kezdtek az országban az 1988-1990-es politikai átmenti időszakban. (,agile”)

Kezdeti nehézségek mellett a család új vállalkozása talpon tudott maradni. „Szabad emberek, magunk urai szerettünk volna lenni a férjemmel. Nem másnál dolgozni, más rabszolgája, alkalmazottja lenni. Ez nehezebb életforma, de sokkal szabadabb. Itt nem 8 órát, hanem 16 órát dolgozunk, de azt szabadon.” - mondja Katalin. (,ambiciózus” ) Aki így folytatja: "Számunkra a kikapcsolódás a természet, mert ebben soha nem csalódunk. A szőlészet családi hagyomány volt."

Rendkívüli elhivatottságuk és szorgalmuk segítette át őket az első évek nehézségein (,motivált”), amely időszakban a magyar családi borászatok közül elsők között váltak szakmailag igazán elismert (1.táblázat), pénzügyileg sikeres vállalkozássá. 


\section{1. számú táblázat: Hangavári Pincészet néhány fontosabb díja Table 1. Selection of key awards of Hangaváry Winery}

\begin{tabular}{|l|c|}
\hline Nemzetközi díjak: \\
\hline \multicolumn{2}{|c|}{ 2011 Japán - Világ legjobb bora 2. hely - 2000-es Esszencia } \\
\hline Magyar díjak: & Aszú 6-puttonyos (1999) \\
\hline \multicolumn{2}{|c|}{ Psszencia (2000.) } \\
\hline 2003. Aranyérem & Késői Furmint (2013) \\
\hline 2007. Aranyérem & Aszú 6p(2013) \\
\hline 2017. Nagyarany & Aszúesszencia (1999) \\
\hline 2019. Aranyérem & Aszúesszencia (2003) \\
\hline \multicolumn{2}{|c|}{ Országos Borverseny } \\
\hline \multicolumn{2}{|c|}{ Bormustra } \\
\hline 2007. Magyarország csúcsbora & Aszú 6-puttonyos (2013) \\
\hline \multicolumn{2}{|c|}{ 6-puttonyos Lapis (2007) } \\
\hline 2009. Legjobb bor
\end{tabular}

Forrás: Hangavári Pincészet

Jánosnak és Katalinnak két gyermeke született. Anita borász lett, aki egy kitérő után, ismét a családi vállalkozásban dolgozik. Fiatalabb Attila informatikus diplomát szerzett. Több évet élt külföldön és számos informatikai fejlesztése, vállalkozása után, most gondolkozik azon, hogy jobban részt vegyen a családi vállalkozás mindennapjaiban.

A szükebb, de biztos megélhetést jelentő munkahely megszűnése (Katalin) és tudatos feladása (János) után kimagasló kreativitásra volt szükségük vállalkozásuk felépítéséhez. Maga az alaptevékenység a borászat is rendkívül kreatív egyéniséget igényel, mivel a természet minden évben, minden fajtánál más és más kihívások elé állítja a borászt, hogy folyamatosan kiváló minőséget tudjon alkotni. A borászathoz szükséges kreativitáson túl a családnak üzleti kreativitásra is szüksége volt, ami leginkább a családfőt, Jánost jellemzett. („kreatív gondolkodású") Ö fejlesztette ki az üzleti modellt, ezen belül egyedi értékesítési modellt is, illetve álmodta és valósította meg a sikeres működés alapjait jelentő fejlesztéseket. (,innovatív”). Anita elmondása alapján nagy stratégiai célkitüzések soha nem voltak a családban, de édesapja folyamatosan új célokat tüzött ki a család és a vállalkozás számára. Ilyen célok voltak az önálló értékesítés megvalósítása, új birtokrészek vásárlása, illetve telepítése, pince vagy a feldolgozó-üzem kialakítása („,célkitüző”). Hudácskó János 2015-ös halálig a család el is érte ezeket a célokat. Az eredeti fél hektárról 15 hektárra növelték a termőterületét, saját feldolgozó és palackozó üzemet építettek fel, az előállított bort pedig saját márkanevük alatt, maguk értékesítik. 2015 óta a család nem tüzött ki lényegi új célt maga elé, a korábban meghatározott „pályán” dolgoznak.

A korábbi célok mindig konkrétak, elérhetőek és megvalósíthatók voltak. János és Katalin munkájában rövid és hosszú távon is ott volt az eredményközpontúság. Ilyen eredmények voltak például a fejlesztések elkészülése vagy szakmai versenyek díjai a folyamatosan növekvő értékesítés mellett. Anita elmondása alapján csak azzal foglalkoznak, 
aminek látszik a közvetlen eredménye. Szociális szakmai kapcsolataikat ápolása helyett („,kapcsolatépítő") idejüket a vállalkozás konkrét napi feladataik elvégzésére fordítják (,eredményközpontú”).

Míg János a célkijelöléssel és üzleti kreativitással, vízióval, segítette a családot, addig Katalin az emberekhez való különleges érzékének csatasorba állításával járult hozzá a vállalkozás sikereihez. Katalin rendkívül inspiráló személyiség, ami munkája során kihat a vállalkozás legtöbb ügyfelére, illetve kevés számú alkalmazottjára is (,inspiráló"). Katalinnak saját koherens felfogása van a bor szerepéről az életben és a jó bor készítésének értélesítésének és fogyasztásának módjáról, (,érték vezérelt") amit szinte szuggesztív módon kommunikál környezetében („hatékonyan kommunikál”).

„A bor mindig kitünő, korrekt legyen. Ez önmagát adja el. A szőlő az első, a munka el legyen végezve. Ez nem kereskedelem. Itt ki van az ember szolgáltatva a természetnek és ezt el kell tudnunk fogadni. A szőlő és bor tartja össze az embereket és az országot. A bor körül jönnek össze az emberek és beszélik meg a dolgaikat" - foglalja össze üzleti hitvallását Katalin.

Ennek a filozófiának része egy magasabb morális mérce, amit saját maga, családja és kollégái elé állít. „Nem adunk el bort kereskedőnek. Bor és ember felett nem alkudozunk! Márpedig a kereskedővel alkudni kell!" - vallja Katalin.

Ezeket a morális értékeket nem csak szavait, hanem minden napi életét áthatja (,értek vezérelt”): olyan ember dolgozhat csak náluk, vagy ahogy ő mondja „érhet a szőlőhöz”, aki szereti azt. Emberi kapcsolataiban a kölcsönös megbecsülés érződik, ezt erősítették meg munkatársai és vásárlói is (,,igazságosan viszonyul másokhoz"). Katalint különösen érdeklik az emberek problémái, („gondoskodó”) közel engedi őket magához ezzel az üzleti életben szokatlanul bensőséget kapcsolatot tud környezetével kialakítani. (,tud bánni az emberekkel”, magas EQ-val rendelkezik") . Érdekes látni Katalint munka közben. A vásárlók, borkostolók minden rezdülését figyeli, és mindenkihez van egy jó szava. Nagyon könnyen alakít ki kapcsolatot a borászatba újonnan betérökkel. A visszatérők, akik akár évek óta nem voltak nála, úgy érzik, mintha tegnap találkoztak volna Katalinnal. Emlékszik a családra, ki hol dolgozik és sokszor még arra is, hogy miröl beszélgettek legutoljára.

A család rugalmasan áll a vállalkozás esetleges kudarcaihoz és sikereihez is. Mindkettőn könnyen túllépnek, (,rugalmas”) ezzel lehetőséget adva maguknak a folyamatos fejlödésre.

János jó mérnökként a racionális döntéseket hozott, míg Katalin a borászati tevékenység vezetőjeként megérzéseire hagyatkozva férjével közösen döntötték el a fontos dolgokat. A döntéshozás most sem egy kézben összpontosul, hanem Katalin és két gyermeke hozzák meg azokat. („,bevon másokat a döntésekbe"). A döntések meghozatalánál mai napig János iránymutatását tartják szem elött :,Semmiből semmi sem lesz! A szőlőnek és a bornak mindent meg kell adni, mert abból lesz a jó termék. Ha valamit csinálunk azt csak kiválóan szabad.” („,eredményközpontú”, ,értékvezérelt”)

A vállalkozás fejlesztésének fontos eleme a céltudatos pénzügyi gazdálkodás. (,pénzügyeket kezeli”) Katalin feladata a pénzügyek kézben tartása, a fejlesztésekre fordítható forrás, illetve az árak meghatározása is. Tudatos pénzügyi gazdálkodás nélkül nehéz elképzelni sikeres vállalkozás építését. Katalin a vállalat pénzügyeit is érték alapon közelíti meg. A család mindig csak saját forrásaiból ruházott be. Soha nem vett fel egy forint kölcsönt vagy fejlesztési támogatást sem. "Jó bort csak szabad ember készíthet és aki bank vagy valaki más felé elköteleződik, az nem szabad. Nem bírom a papírt, mert az nem hagy élni. Az ügyeket, amik adminisztrációval járnak, ha lehet kerüljük." foglalja össze vállalat-finanszírozással kapcsolatos filozófiáját Katalin. 
2. táblázat: Hangavári pincészet fejlődése számokban Table 2. Development of Hangaváry Winery in numbers

\begin{tabular}{|c|c|c|c|c|c|c|c|}
\hline Hangvavári Pincészet számokban & 1990 & 1995 & 2000 & 2005 & 2010 & 2015 & 2019 \\
\hline Birtok terület (ha) & 5 & 7 & 10 & 15 & 15 & 15 & 15 \\
\hline Termés átlag (hl/ha) & 60 & 60 & 45 & 35 & 30 & 22 & 20 \\
\hline Összes termelés (hl) & 300 & 420 & 450 & 525 & 450 & 330 & 300 \\
\hline Éves termelési érték (mio Ft/év) & 3 & 10,5 & 15,7 & 37,3 & 76,5 & 100,3 & 165,6 \\
\hline Lédig/palack arány & 1 & 1 & 0,8 & 0,6 & 0,4 & 0,3 & 0,1 \\
\hline Lédig ár (Ft/l)) & 100 & 250 & 250 & 350 & 500 & 800 & 1200 \\
\hline Palackos ár (Ft/l) & 0 & 0 & 750 & 1250 & 2500 & 4000 & 6000 \\
\hline Lédig mennyiség (l/év) & 300 & 420 & 360 & 315 & 180 & 99 & 30 \\
\hline Palackos mennyiség (l/év) & 0 & 0 & 90 & 210 & 270 & 231 & 270 \\
\hline Vendéglátás (fő/év) & 0 & 0 & 5000 & 5000 & 3500 & 1500 & 2500 \\
\hline Átlagos vendéglátó ár (Ft/fö) & 0 & 0 & 5000 & 5000 & 7000 & 10000 & 12500 \\
\hline Vendéglátás árbevétel (mio Ft/év) & 0 & 0 & 25 & 25 & 24,5 & 15 & 35 \\
\hline Összes érték-teremtés (mio Ft/év) & 3 & 11 & 41 & 6 & 101 & 115 & 201 \\
\hline Dolgozók a családból (fö) & 4 & 4 & 4 & 4 & 4 & 3 & 3 \\
\hline Állandó alkalmazott (fó) ${ }^{1}$ & 0 & 1 & 5 & 5 & 5 & 5 & 3 \\
\hline
\end{tabular}

Forrás: Hangavári Pincészet

Hudácskó család esetében ez a fejlődési pálya (2. táblázat) rendkívül sikeres a közepes méretü családi vállalkozás szintjéig, ám ez a fejlődés ezen a szinten megragadt. Ennek oka, hogy a vállalkozók nem akarnak és nem is tudnak túllépni a családi vállalkozás szervezeti keretein, vállalkozói-vezetői kompetenciáik erre a vállalati szintre megfelelők. $\mathrm{Az}$ összes munkafolyamat korábban Katalin és János, most pedig Katalin és Anita, kisebb mértékben Attila, kontrollja alatt van. Nem tudnak élni a delegálás és az ezzel járó minőségirányítás kompetenciáival. („hatékonyan delegál” hiánya)
A vállalkozás kultúrájának fontos része a tulajdonosok állandó, közvetlen szerepvállalása minden egyes munkafolyamatban, bele értve a fizikai munkákat is. („szervezetet fejleszt” hiánya). A vállalkozásban néhány napot eltöltve szembetünővé válik, hogy a család két hölgy tagja, akik állandóan a vállalkozásban dolgoznak és Attila is, amikor Bodrogkeresztúron van, minden munkafolyamatban részt vesznek. Nem csak irányítanak, hanem az alkalmazottakkal együtt végzik a fizikai munkát a szőlőben, a pincében és a vendégek kiszolgálásánál is.

Az állandó alkalmazottakon túl a vállalkozás a nagyobb mezőgazdasági és borászati idénymunkák idején rövid távra munkaerőkölcsönzőktől 8-10 fó segítséget vesz igénybe. 
A valós vállalati szervezet hiánya a korai fázisokban előnyére is válhat egy vállalkozás fejlödésének. A közvetlen tulajdonosi kontroll segít a költségek alacsonyan tartásában, a minőség biztosításában, információk akadálymentes áramlásában, a gyors döntéshozásban. Ez az előny Churchill és Lewis (1983) vállalkozási életpálya szakaszai alapján a negyedik és ötödik szakaszban - „felszálló ág” és „konszolidált erőforrások” - válik szinte leküzdhetetlen hátránnyá. Ezen túlmenően, az alapító tulajdonosok távozása után, amennyiben nem változik ez a speciális, szervezeti kultúra által vezérelt müködési modell, a vállalkozás szinten tartását és végül létét is veszélyeztetheti. A család által jól azonosított külső piaci veszélyek mellett, idővel, de legalább ugyan olyan erősséggel megjelenik egyes kompetenciák belső hiányából fakadó gyengeség.

$\mathrm{Az}$ üzleti modell sérülékenységére példa az értékesítési és marketing gyakorlat. Jelenleg Katalin személyéhez köthetô a vállalkozás értékesítésének száz százaléka. Ö ismeri az ügyfeleket, (,,felsimeri a fogyasztói igényeket") akik hozzá kötődnek („,kapcsolatokat épít”), a bor kiváló minősége mellett, az ő személyes kisugárzása miatt vásárolnak
Hangavárit (,inspiráló”). Hasonló kisugárzása, azaz kommunikációs és inspiráló kompetenciája, sem Anitának, sem Attilának nincs. Ma ök nem lennének képesek egy ilyen értékesítési a modellt a jelenlegi szinten működtetni. Idővel Katalin szerepvállalásának csökkenése elkerülhetetlen lesz. Erre felkészülni nem elég az általa végzett feladatok Anitának és Attilának való átadásával, ahogy az a borászati feladatok esetében meg is történt, hanem egy értékesítési modell váltásra lesz szükség, ami nem Katalin személyes kompetenciáira, hanem a vállalkozás fenntartható szervezeti kompetenciáira épít.

\section{VÁLLALKOZÓI KOMPETEN- CIÁK CSOPORTOSÍTÁSA}

\section{ENTREPRENEURIAL COMPE- TENCY CLASSES}

Amennyiben táblázatba (3. táblázat) rendezzük a Hudácskó-család vállalkozói kompetenciait érdekes mintázatokat találhatunk.

3. táblázat: Hudácskó család vezetői kompetenciái

Table 3. Hudácskó family's leadership competencies

\begin{tabular}{|c|c|c|c|c|}
\hline János & Katalin & Anita & Közös & $\begin{array}{c}\text { Kompetencia } \\
\text { hiánya } \\
\text { azonosítható }\end{array}$ \\
\hline $\begin{array}{l}\text { Stratégiai } \\
\text { gondolkodású }\end{array}$ & Motiváló & Prioritásokat tüz ki & Szakértő & $\begin{array}{l}\text { Hatékonyan } \\
\text { delegál }\end{array}$ \\
\hline $\begin{array}{c}\text { Kreatív } \\
\text { gondolkodású }\end{array}$ & Hire and staff & Célkitüző & Ambiciózus & $\begin{array}{l}\text { Szervezet- } \\
\text { fejlesztő }\end{array}$ \\
\hline Innovatív & $\begin{array}{l}\text { Hatékonyan } \\
\text { kommunikál }\end{array}$ & $\begin{array}{c}\text { Ismeri az üzleti } \\
\text { környezetet }\end{array}$ & Mutivált & Kapcsolatépítő \\
\hline Vízionárius & $\begin{array}{l}\text { Demonstrate } \\
\text { interpersonal skills }\end{array}$ & & Érték-vezérelt & $\begin{array}{l}\text { Vízionárius } \\
\text { (2015. után) }\end{array}$ \\
\hline \multirow[t]{7}{*}{$\begin{array}{c}\text { Ismeri az üzleti } \\
\text { környezetet }\end{array}$} & Kapcsolatépítő & & Agilis & \\
\hline & $\begin{array}{l}\text { Magas EQ-val } \\
\text { rendelkező }\end{array}$ & & $\begin{array}{c}\text { Jól boldogul } \\
\text { bizonytalan } \\
\text { környezetben }\end{array}$ & \\
\hline & $\begin{array}{l}\text { Gondoskodó, } \\
\text { Megközelíthető }\end{array}$ & & $\begin{array}{c}\text { Eredmény- } \\
\text { orientált }\end{array}$ & \\
\hline & Bizalomépítő & & $\begin{array}{c}\text { Bevon másokat a } \\
\text { döntésekbe }\end{array}$ & \\
\hline & Inspiráló & & Rugalmas & \\
\hline & $\begin{array}{l}\text { Igazságosan } \\
\text { viszonyul } \\
\text { másokhoz }\end{array}$ & & $\begin{array}{l}\text { Felismeri a piaci } \\
\text { igényeket }\end{array}$ & \\
\hline & $\begin{array}{c}\text { Kézben tartja a } \\
\text { pénzügyeket }\end{array}$ & & Stratégia-alkotó & \\
\hline
\end{tabular}

Forrás: saját elemzés 
A fenti táblázatból kiolvasható, hogy a család tagjaiban közösen megjelenő kompetenciák, azok, amelyek a vállalkozás indításához és a nehézségek leküzdéséhez szükséges személyes motivációt és - kisebb mértékben - szakértelmet biztosító kompetenciák. E mellett az eredmény-központúság, a feladatok végrehajtására való képesség jelenik meg közös halmazként. Számos kutatás született a vállalkozóvá válás megértésére. Szerb-Lukovszki (2014) szerzőpáros egy soktényezős modellként írja le a folyamatot, amelynek külső és belső tényezők kölcsönhatásából áll. A belső tényezőket, amelyeket, mint számos belső tulajdonság, attitüd, magatartási elemek határoztak meg, segíthet jobban megérteni a személyes késztetést magában foglaló kompetencia-csoport.

Ha ez egyedileg megjelenő kompetenciákat vizsgáljuk János és Katalin esetében egy egymástól eltérő kompetencia-profil rajzolódik ki. Kizárólag Jánosra jellemző kompetenciákat külön vizsgálva egy tervező személyiség jelenik meg, Ö az, aki a vállalkozás vízióját és stratégiát alakította és az innováció motorja volt. Katalin speciális kompetenciái a társas kapcsolatokban keresendők. Ö érzi az emberek igényeit és kiváló kompetenciákkal rendelkezik a kapcsolatok kialakítására, fenntartására legyen szó kollégákról vagy ügyfelekről. Anita és
Attila esetében nem határozható meg ilyen markáns profil. Anitára, a család többi tagjától elkülönülten vizsgálva, leginkább az operatív tervező kompetenciák jellemzők. Attila, mivel a vizsgált időszakban nem töltött be meghatározó szerepet a vállalkozás életében, így nem volt lehetőség az ö kompetenciának feltérképezésére. Elképzelhető, hogy Anita és Attila kompetencia-készletének megjelenése bővülni fog, amikor Katalin is visszavonul a vállalkozás napi vezetésétől és a második generáció fogja meghatározni a vállalkozás jövőjét.

Markánsan és jól csoportosíthatóan jelennek meg azok a kompetenciák, amelyekkel a család egyik tagja sem rendelkezik és nem is tartják őket maguk számára fontosnak. Ezek a kompetenciák nagyobb szervezetek fejlesztéséhez és vezetéséhez szükségesek.

A fenti elemzésből az tünik ki, hogy 5 jól elkülönülő (4. táblázat) kompetencia-csoportot azonosíthatunk: személyes-késztetés, tervező, szociális, megvalósító és szervezeti. Ezek a kompetencia-csoportok az esettanulmányban jellemzően elkülönülve jelennek meg és a vállalkozások szempontjából is külön értelmezhetők, a vállalkozói feladatok sikeres elvégzéséhez és fejlődési lépések elérése szempontjából is kiemelten fontosak.

\section{4. táblázat: Hudácskó családban megjelent vezetői kompetenciák csoportosítása Table 4. Competency classes of the Hudácskó family's competencies}

\begin{tabular}{|c|c|c|c|c|}
\hline Személyes & Szociális & Tervező & Megvalósító & Szervezeti \\
\hline Agilis & Kapcsolatépítő & $\begin{array}{l}\text { Felismeri a } \\
\text { fogyasztói } \\
\text { igényeket }\end{array}$ & Ereményközpontú & $\begin{array}{c}\text { Hatékonyan } \\
\text { delegál }\end{array}$ \\
\hline Ambiciózus & Bizalomépítő & Célkitűző & $\begin{array}{c}\text { Kezeli a } \\
\text { pénzügyeket }\end{array}$ & Szervezetfejlesztő \\
\hline Motivált & Gondoskodó & Prioritásokat tűz ki & $\begin{array}{l}\text { Bevon másokat a } \\
\text { döntésekbe }\end{array}$ & $\begin{array}{c}\text { Fejleszti az emberi } \\
\text { állományt }\end{array}$ \\
\hline Szakértő & $\begin{array}{l}\text { Hatékonyan } \\
\text { kommunikál }\end{array}$ & Stratégia-alkotó & Rugalmas & Hálózat-építő \\
\hline $\begin{array}{l}\text { Jól boldogul } \\
\text { bizonytalan } \\
\text { környezetben }\end{array}$ & $\begin{array}{l}\text { Tud bánni az } \\
\text { emberekkel }\end{array}$ & Vízionárius & & \\
\hline \multirow[t]{3}{*}{ Érték vezérelt } & $\begin{array}{c}\text { Magas EQ-val } \\
\text { rendelkezik }\end{array}$ & & & \\
\hline & Inspiráló & & & \\
\hline & $\begin{array}{l}\text { Motiváló } \\
\text { Igazságosan } \\
\text { viszonyul } \\
\text { másokhoz }\end{array}$ & & & \\
\hline
\end{tabular}

Forrás: saját elemzés 
Amennyiben a kompetenciák fenti csoportosítását alkalmazzuk a borászat tulajdonosaira és vezetőire megfigyelhetők a jól elkülönülő vezetői profilok. János a tervezö, Katalin esetében pedig a szociális kompetenciák jelennek meg dominánsan. Szervezeti kompetenciák hiánya és János halálát követően a vízió-alkotás hiánya, mint hiányzó tervező kompetencia mutatható ki. Katalin rendel- kezik a legsokrétűbb kompetencia-készlettel, ami nem meglepő hiszen ő alapítója és vezetője a vállalkozásnak 30 éve. Anita esetében kérdéses, hogy Katalin jövőbeni kiválását követően ő maga tud-e egyedül, vagy Attilával közösen tud-e majd használni egy hasonlóan összetett kompetencia-készletet.

\section{1. ábra: Kompetencia-osztályok szerinti kompetenciák megjelenése a borászat tulajdonosai, vezetôi között}

Figure 1. Competency classes of the competencies identified of the owners and managers of the winery

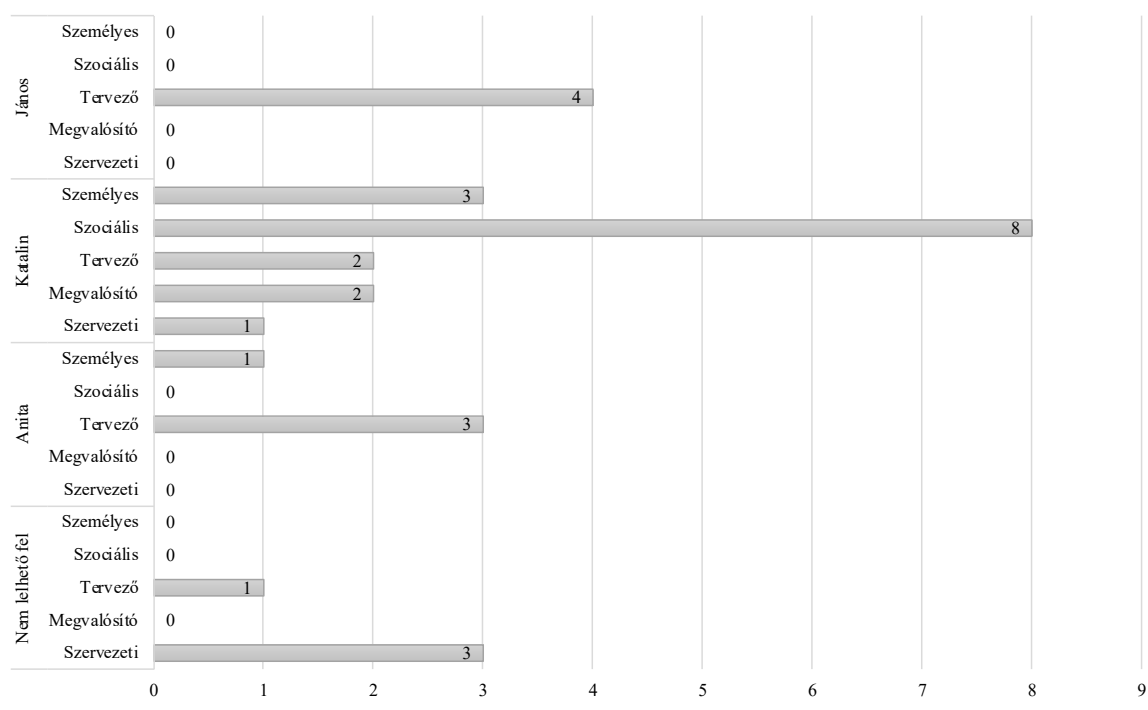

Forrás: saját elemzés

A fenti ábra kizárólag az egyedi kompetenciákat mutatja be. Ha figyelembe vesszük a közösen megjelenő kompetenciákat is, akkor jól látható, hogy a személyes motiváció és szakmai ismeretek az alapja egy vállalkozás indításának és sikeres vezetésének. E mellett a szervezeti kompetenciák kivételével a másik négy kompetencia-osztály (2. ábra) elemei mind megjelennek a vállalkozás tulajdonosai között, ezzel biztosítva a vállalkozás sikerességét. Ezek alapján úgy tűnik, hogy bizonyos méret és életszakasz eléréséhez a személyes, szociális, tervező és megvalósító kompetenciák együttes megléte szükséges és elégséges egy sikeres vállalkozás felléptéséhez. A szervezeti kompetenciák szükségessége ezt követően jelentkezik. 


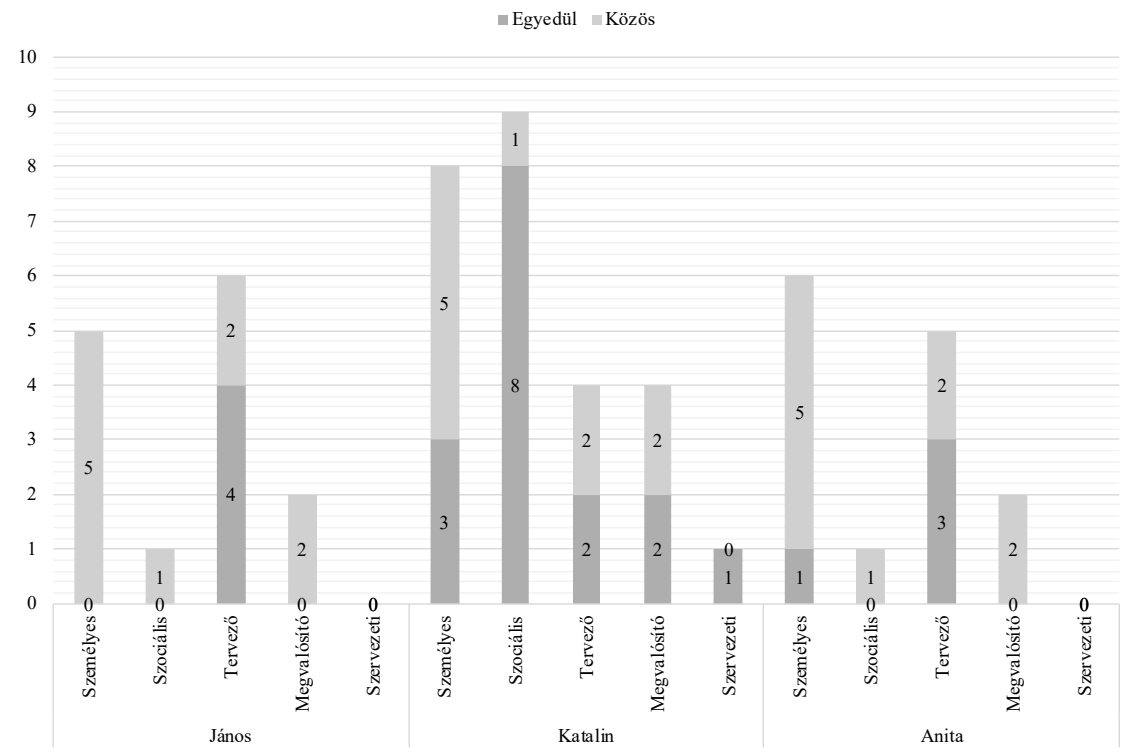

Forrás: saját elemzés

Részben ezt a problémát azonosította John Hamm (2002) is. Ö azt állítja, hogy egyes szokások és képességek, amelyek sikeressé teszik a vállalkozókat kimondottan gátjaivá válnak a vállalkozás későbbi fejlődésének. Hamm továbbá megjegyzi, hogy a problémák akkor kezdődnek, amikor néhány fös csapatból szervezet kialakítása szükséges. Négy fő vállalkozói szokást mutat be, amelyek akadályai a fejlődésnek. Ezek közül kettő, túlzott lojalitás kis számú korábbi munkatárshoz, illetve az izolációban való tevékenység (kapcsolatépítés, networking hiánya) releváns a nagyobb szervezet kialakításához szükséges vállalkozói vezetői kompetenciák szempontjából. Érdekes, hogy mindkét szokás jellemző a Hudácskó családra. Anita, mint erény emelte ki, hogy a család szinte semmilyen szakmai vagy érdekérvényesítési szervezetben nem vesz részt, szociálisan nem integrálódnak, divatos szóval nem ,netwörkölnek”, ami - Hamm szerint - fontos eleme lenne a hosszú távú szervezetfejlesztési tevékenységnek. 
3. ábra: Vállalkozói vezetői kompetenciák eloszlása a Hangavári pincészetben Figure 3. Distribution of leadership competences in the Hangavári Winery

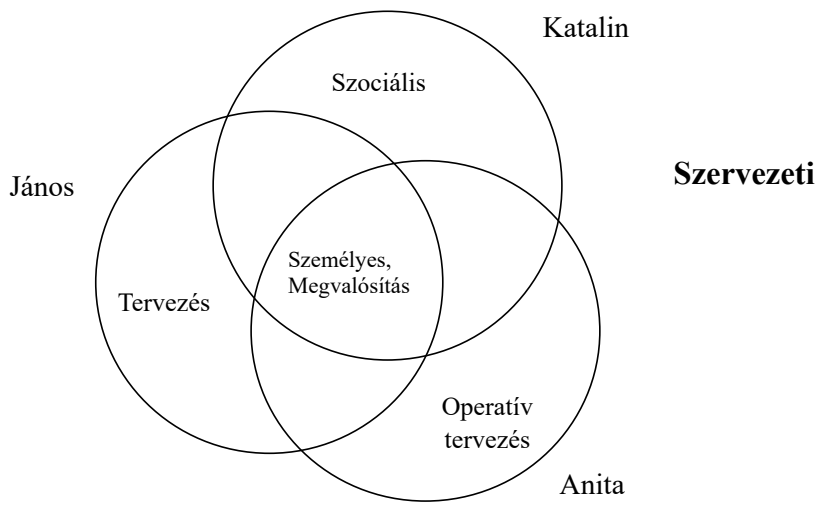

Forrás: saját elemzés

A szervezeti kompetenciák hiánya egy általános probléma a hazai családi vállalkozások esetében. A növekedő hazai családi vállalkozások Salamonné (2006) modellje szerint a Kreativitás fázisában vannak. Ennek a ciklusnak a végén az irányítási krízis jelenik meg. A folyamatokat újra kell szervezni, új rendszereket kell bevezetni a pénzügyi és üzleti folyamatokra. Az ösztönzés területét is meg kell változtatni. Formalizálni kell a szervezetet, hatásés felelősségi köröket kell meghatározni. Ennek a szakasznak a végén valójában a személyes vezetés válsága jelenik meg. Az intuitív, ad-hoc vezetésről át kell térni a professzionális vezetésre. Az alapítók, a jelenlegi vezetők közül az tudja sikeresen felvállalni ezt az új szerepet, akinek adottságai, képességei, tudása lehetővé teszi ezt. (Bogdány és tsai 2019, 72). A vezetöi kompetencia-elemzésünk alapján a fenti problémát úgy pontosíthatjuk, hogy a vállalkozás számára belső vagy külső forrásból szervezeti vezetöi-kompetenciákkal is rendelkezö vezetöt kell találnia.

\section{A KOMPETENCIA-ADATBÁZIS STRUKTURÁLÁSA ÉS KÖVET- KEZŐ KUTATÁSI LÉPCSŐ}

\section{STRUCTURING THE COMPE- TENCY DATABASE AND THE NEXT STEPS OF RESEARCH}

Az esettanulmányban megjelenő kompetenciák és azok mintázatai alapján kialakított öt kompetencia-csoport jól alkalmazható a teljes kompetencia-adatbázisra. A 120 elem mindegyike besorolható az öt kompetencia-csoport valamelyikébe. A kutatás következő lépéseiben a teljes kompetencia-adatbázis tesztelhető a kialakított csoportok alapján, ami a releváns kompetenciák további vizsgálatának és strukturálásának teremti meg a lehetőségét.

Management tudományok azon belül is a szervezeti magatartás kutatásának fontos eleme a metaforák használata. A szervezetek leírása, mint élö organizmusok egy elterjedt gyakorlat. (Faghih et al. 2016). A vállalkozók hasonló szerepet játszanak egy vállalat fejlödése életében, mint egy őssejt az élő szervezet fejlődésében. Míg az őssejt tartalmazza azt a képességet, hogy a későbbi élő szervezet minden egyes differenciált sejtje, szövete és szerve fejlődéséhez biztosítsa az információt és ez által a képességet, úgy a sikeres vállalkozók rendelkeznek azokkal a kompetenciákkal, amelyek 
alapjai egy differenciált üzleti szervezet kialakulásának. A későbbi szervezet funkcionális vezetőinek kompetenciái, illetve azok egy fontos részének már a sikeres vállalkozókban is meg, kell, hogy jelenjenek. A funkcionális vezetők, illetve az általános szervezeti vezetők (pl. vezérigazgató) szokásos vezetői kompetenciáinak összessége viszont nem határozza meg a sikeres vállalkozói kompetenciákat. A vállalkozóknak rendelkezniük kell ezen túlmenő és eltérő kompetenciákkal. Abban az esetben, ha egy vállalkozás megfelelő piacra talált és a piacot kiaknázni képes üzleti modellel rendelkezik, sok esetben, a vállalkozó kompetencia-készlete dönti el, hogy milyen növekedési pályát tud majd befutni.

Amennyiben egy vállalkozás nem ütközik külső növekedési korlátokba (pl. piaci, jogi, finanszírozási) feltételezhetjük, hogy a növekedésének és sikereinek egyik fontos meghatározó eleme a vezetők kompetencia-készletének minősége és sokszínüsége. Érdekes jövőbeni kutatási irány lesz megvizsgálni, hogy egy vállalkozás egyes életfázisaiban, illetve a vállalkozás méretéhez viszonyítva kimutatható-e valamilyen kapcsolat az egyes vezetői kompetenciák vagy kompetencia-csoportok meglétével vagy hiányával.

\section{HIVATKOZÁSOK}

\section{REFERENCES}

Bakacsi Gy. (2010), Szervezeti magatartás alapjai, Budapest Corvinus Egyetem, Aula Kiadó Kft.

Bogdány, E., Szépfalvi, A. \& Balogh, Á., (2019), Hogyan tovább családi vállalkozások? Családi vállalkozások utódlási jellemzői és nehézségei. Vezetéstudomány, 50 (2), pp.72-85. DOI: http:// dx.doi.org/10.14267/veztud.2019.02.06.

Buzady, Z., \& Almeida, F. (2019), FLIGBY - A Serious Game Tool to Enhance Motivation and Competencies in Entrerenurship. Informatics, 6 (3), 27. DOI: doi:10.3390/informatics6030027

Boyatzis, R. E. (1982), The competent manager: A model for effective performance. New York, Wiley-Interscience.

Churchill, N.C. Lewis, V (1983), Five stages of small buisness growth, Boston, Harvard Business Review 1985 May, Harvard Business Publishing. 30-50

Faghih, N., Bavandpour, M. \& Forouharfar, A., (2016), Biological metaphor and analogy upon organizational management research within the development of clinical organizational pathology. QScience Connect, 2016(2). DOI: http:// dx.doi.org/10.5339/connect.2016.4.

Hamm, John. (2003), Why entrepreneurs don't scale. Harvard Business Review. 80. 110-5, 134

Horváth, D-Mitev, A (2015), Alternativ kvalitativ kutatási kézikönyv, Budapest, Alinea Kiadó

Kyndt, Eva, \& Baert, Herman. (2015), Entrepreneurial competences: Assessment and predictive value for entrepreneuship. Journal of Vocational Behavior, 90, 13-25, DOI: https://doi. org/10.1016/j.jvb.2015.07.002

Mihalkovné Szakács K. (1994), Vállalkozási Ismeretek Oktatása vs. Vállalkozói Kompetenciák Fejlesztése, Vezetéstudomány, XLV. (10) $49-57$

Rașcă, L., \& Deaconu, A. (2018), Entrepreneurial motivators and competencies - main drivers of entrepreneurial success, Proceedings of the International Conference on Business Excellence, 12(1), 864-874. DOI: 10.2478/picbe2018-0077

Robles, L. \& Zárraga-Rodríguez, M., (2015), Key Competencies for Entrepreneurship. Procedia Economics and Finance, 23, pp. 828832. DOI: http://dx.doi.org/10.1016/s22125671(15)00389-5.

Sandberg, J. (2000), "Understanding human competence at work: An interpretative approach", in 
Tóthné, T. és Hlédik, E. (2019) Kompetenciaelvárások értelmezése egy mélyinterjús kutatás eredményei alapján, Marketing \& Menedzsment, 52(2), 59-68

Spencer, L. M.Spencer, Jr. PhD S. M. (1992), Competence at work. New York, John Wiley and Sons, Inc.

Szerb L., Lukovszki L. (2014), Magyar Egyetemi Hallgatók Vállalkozási Attitüdjei és az Attitűdöket Befolyásoló Tényezõk Elemzése A Guesss-Felmérés Adatai Alapján, Vezetéstudomány, XLIV (7-8) 30-40

Tittel, A., Terzidis, O. (2020), Entrepreneurial competences revised: developing a consolidated and categorized list of entrep reneurial competences. Entrep Educ, DOI: https://doi. org/10.1007/s41959-019-00021-4

Tóthné, T. és Hlédik, E. (2019), Kompetenciaelvárások értelmezése egy mélyinterjús kutatás eredményei alapján, Marketing \& Menedzsment, 52(2), 59-68.

Zsigmond, S., (2018), Vállalkozásfejlesztési mentorálási folyamat a karmester szemszögéből, avagy milyen elvárásoknak kell megfelelnie egy mentornak és hogyan tud sikeresen vezetni egy folyamatot? Vezetéstudomány, 49 (10-11), 17-32 DOI: http://dx.doi.org/10.14267/veztud.2018.10.02.

www.hangavári.hu (letöltve legutoljára: 2019. május 20-án.)

https://www.leadershipcompetencieslibrary.com/ (Letöltve: 2019.12.22)

\section{Esettanulmány megírásához készített és felhasz-} nált interjúk:

1. Barna Istvánné, Bodrogkisfalud, 2019. május 8-án.

2. Gyenes Levente, Budapest, 2019. május 28-án.

3. Hudácskóné Magyar Katalin, Bodrogkisfalud, 2019. május 7-én.

4. Hudácskó Anita, Bodrogkisfalud, 2019. május 7-én.

5. Hudácskó Attila, Bodrogkisfalud, 2019. május 8-án.

6. Király Gellért, Budapest, 2019. május 10-én.

7. Szappanos Péter, Budapest, 2019. május 24-én. 
Kassai Ákos, doktorjelölt akos.kassai@uni-corvinus.hu Budapesti Corvinus Egyetem

\section{Entrepreneurial Leadership Competencies in the Light of the Case of Hangaváry Winery in Tokaj}

\section{THE AIMS OF THE PAPER}

This exploratory paper summarizes the findings of the first step of a multi-stage research into entrepreneurial leadership competencies. The first step aims to identify and structure leadership competencies specific for successful entrepreneurs. Creating such an entrepreneurial leadership competency model may lead to a number of practical applications. Just naming a few, business schools with entrepreneurial development programs developing their curriculum, venture capital firms' selection and portfolio-management decision may benefit from such a model. The results may improve the incubation programs of entrepreneur accelerators and also consultants working in the sector might find it useful to better understand their clients' issues.

\section{METHODOLOGY}

In this research, preceded by literature research, I identify key entrepreneurial leadership competencies in the case study of a successful Hungarian Winery. The paper presents a gap-analysis for the competency-set of the entrepreneurs in the case-study and highlights possible consequences of missing key leadership competencies. The paper aims to identify, specify and structure a group of competencies considered as key success factors for prosperous entrepreneurs. Key competencies were identified by coding the case-study and also applied qualitative and simple quantitative research tools.

\section{MOST IMPORTANT RESULTS}

Five groups of competencies were identified in the study: personal urge, planning, social, executive and organizational. It is very rare that a single person is armed with the essentially divers set of competencies. Combined competency sets of members of family businesses or other corporate ventures are more likely to present the necessary, manifold competencies.

\section{RECOMMENDATIONS}

Entrepreneurs play a similar role for established enterprises like stem cells in the development of living organizations. While stem cells are with the unique ability to develop into specialized cells of an organization to grow new tissues and organs, entrepreneurs also need to be equipped with many competencies of most of the functional leaders operating in large, well-structured corporations.

Looking at the identified 5 competency-groups the personal urge provides motivation to function as an entrepreneur and all entrepreneurs shall possess a form of those competencies. Leveraging planning, execution or social competency-groups vary in entrepreneurs based on the individual leadership style. Mastering the organizational competencies may become more important for entrepreneurs leading mature ventures and those play a significant role to build sustainable, healthy, and growing enterprises.

Keywords: entrepreneurship, leadership, competencies, family business 